Review of

ECONOMICS

and

INSTITUTIONS
Review of Economics and Institutions

ISSN 2038-1379 DOI:10.5202/rei.v10i2.273

Vol. 10 - No. 2, Fall-Winter 2019 - Article 1

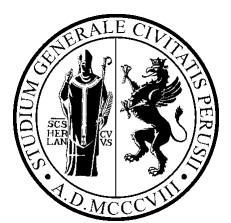

www.rei.unipg.it

\title{
The Political and Economic Role of Elites in Persecution: Evidence from Witchcraft Trials in Early Modern Scotland
}

\author{
Cornelius Christian ${ }^{\bowtie}$ \\ Brock University
}

\begin{abstract}
Persecution, as a political and economic phenomenon, can be abetted by the resources of a nation's elite. To demonstrate this, I focus on a case study: witchcraft trials in Early Modern Scotland (1563-1727), a largely agricultural economy. I find that favourable growing temperatures predict more trials. My main empirical specification survives various robustness checks, including accounting for outliers. During this time, witchcraft was a secular crime, and it was incumbent on local elites to commit resources to trying alleged witches. Turning to mechanisms, I find that positive price shocks to export-heavy, taxable goods predict more witch trials, while price shocks to Scotland's main subsistence commodity, oats, do not. This is consistent with the explanation that as elite income increased, more resources were devoted to witchcraft prosecutions; I cite anecdotal evidence that a different judicial proceeding, sexual trials in Aberdeen, experienced a similar trend.
\end{abstract}

JEL classification: D74; N13

Keywords: Witchcraft; Elites; Persecution; Price shocks

\footnotetext{
Acknowledgments: An anonymous referee and the editor of this journal provided helpful suggestions. I am also grateful to Toke Aidt, Robin Briggs, James Fenske, Julian Goodare, Kevin O'Rourke, Christopher Roth, Stefan Saftescu, Raul Sanchez de la Sierra, James Wisson, and participants at Oxford's Gorman Workshop, the Dalhousie University seminar series and the Canadian Economics Association Conference for help and suggestions. Any errors are my own.
}

$\bowtie$ Address: Plaza Building, 500 Glenridge Avenue St. Catharines, ON L2S 3A1. Mail: cchristian2@brocku.ca.

\section{Recommended Citation}

Christian, C. (2019). The Political and Economic Role of Elites in Persecution: Evidence from Witchcraft Trials in Early Modern Scotland. Review of Economics and Institutions, 10(2), Article 1. doi: $10.5202 /$ rei.v10i2.273

Retrieved from http://www.rei.unipg.it/rei/article/view/273 


\section{Introduction}

Today's wealthiest countries have strong fiscal and legal state capacity (Dincecco and Katz, forthcoming). Centralized states are associated with beneficial outcomes: less poverty (Michalopoulos and Papaioannou, 2013), more stability (Blattman and Miguel, 2010; Besley and Persson, 2011), and better public goods provision (Acemoglu et al., 2014; Dell, 2017). Indeed, the correlation between high living standards and various state capacity measures is well established (Johnson and Koyama, 2017).

Yet there is a deleterious, and even dark, side to state capacity. The political scientist Raul Hillberg (1961) details the grutesque political and economic architecture of the Holocaust, finding that a well financed and organized Nazi state facilitated genocidal ghettos and concentration camps. Tilly (1990) finds that state formation is often violent, and that early nation states were, in essence, organized crime syndicates writ large, offering protection in exchange for rents. More recent evidence also suggests that state capacity can facilitate persecution (Heldring, 2017; Bloxham, 2008; Rae, 2002).

In this paper, I focus on how elites, as state actors, can influence policy to drive persecution. Here, I define an 'elite' person as one who wields significant political or legal power over others; elites include nobles, wealthy merchants, and sherrifs. Mechanisms through which elites can generate hatred and persecution have been investigated before (Glaeser, 2005; Anderson et al., 2017), but few if any studies have examined, empirically, how economic resources can mould elite actions. In this regard, I am especially interested in how economic shocks affect elite income and spending: if persecution is a vital part of an elite's choice function, then to what extent does a rise in elite resources cause persecution to proliferate?

To help answer this question, I use data from Early Modern Scotland (1563-1727) to examine a particular type of persecution, made possible through strong legal state capacity, as well as local-level elite resources: witch hunts, which were motivated by a genuine belief that witches are evil. Scottish law, which made witchcraft a secular crime in 1563, required local elites - lairds, burgesses, sheriffs, and others - to commit resources to trying witches. When these resources, which were mainly derived from taxation of Scottish economic activity, were more ample, witchcraft prosecutions increased. In particular, there were five stages of a Scottish witchcraft prosecution. First, the witch had to be identified. Secondly, local communities had to invest time and funds into gathering evidence. Third, such evidence was couriered to Edinburgh, in order to receive official government approval to proceed with a trial. In the fourth stage, the local community would stage a trial, paying for the requisite expenses. Finally, if the witch was convicted, and she usually was, then she would be executed. At each stage of this process, elites had to use their locally-derived tax revenue in order to purge the 
land of witchcraft, through formal legal means.

Consistent with this, and given that Scotland was an agricultural economy, I find that favourable (warmer) temperatures predict more trials. This is robust to county-specific time trends, different specifications, placebo tests using forward lags, and accounting for peaks and troughs (outliers). This fits with the theoretical prediction that when agricultural output improves due to better weather, elites' tax income rises, which allows them to spend more on witchcraft trials.

Turning to mechanisms, I document secondary historical evidence that Scottish elites derived income from export-heavy, taxable commodities such as herring and wool. When the prices of these items rose, the elites could extract more taxable income, which could then permit more trials to be funded. Using commodity prices as a proxy variable for tax income, I find that positive price shocks to herring and wool predict more trials. As a falsification exercise, I find that shocks to Scotland's main subsistence commodity, oats, do not predict trials, since this crop was not a major source of taxable income, and was mainly consumed by peasants. I provide historical evidence that these patterns were not due to avarice, since witchcraft suspects had little valuable property, and trials themselves were costly.

My paper proceeds as follows. In Section 2, I review related literature, and demonstrate my study's contribution. In Section 3, I provide historical background. In Section 4, I describe my empirical strategy and data in order to identify the causal impact of shocks on witch trials. Section 5 provides my results, along with robustness checks and mechanisms. In Section 6, I conclude with a short reflection on policy applications.

\section{Related Literature}

Elite resources and oppression are evident throughout history's great persecutions; the 1915-1916 Armenian genocide, for example, relied upon local authorities, empowered with Young Turks ideology, rounding up and killing Armenians. These local Ottoman social and political elites had been indoctrinated with anti-Christian ideology, due to Ottoman territorial losses to Europeans and Russia (Bloxham, 2008). In a later violent episode, the Bosnian civil war of 1992-1995, local Muslim elites, for economic reasons, fomented Muslim on Muslim slaughter, in order to cement their authority over competing Muslim leaders (Christia, 2008). More recent work has emphasized that such elite competition can be key in explaining state formation (Garfias, 2018). In my study, I am likewise concerned with the interactions between state capacity, local elites, and persecution of so-called witches.

Scottish elites required resources in order to try suspected witches; my study investigates the idea that times of economic well-being can cause violence, in the form of witchcraft persecutions, and thus reinforces and illus- 
trates an important literature in this area (Hsiang et al., 2013; Collier and Hoeffler, 2004; Miguel et al., 2004). In particular, Bazzi and Blattman (2014) have stressed the need for case study evidence in order to disentangle underlying mechanisms. By examining witchcraft trials in Early Modern Scotland, I focus on a single case study, and am therefore able to uncover mechanisms that drive the link between temperature shocks and witch trials, while limiting confounding factors. This is an important contribution, since economic channels that drive conflict and violence are still ill understood, though recent research has made progress in this direction (Dell, 2015; Fetzer, 2014; Dube and Vargas, 2013).

Dube and Vargas (2013) use data on the Colombian conflict in the 1990s and early 2000s to identify two widely-discussed mechanisms: the opportunity cost effect, and the rapacity effect. The former effect states that when the value of being violent rises, relative to other activities, then violence itself increases (Besley and Persson, 2011; Dal Bo and Dal Bo, 2011; Angrist and Kugler, 2008). For example, if agricultural wages decline, then farm workers are more likely to join guerrilla squads. The rapacity effect, and its analogue the state prize effect, claims an opposite impact: higher income means that there is more to fight over (Hirshleifer, 1991; Grossman, 1999). If, say, oil prices rise, then paramilitaries are more likely to attack oil fields and kidnap oil executives. Although I find that positive environmental shocks predict more witch trials, this is not due to a rapacity effect. Rather, it is due to the ability of local elites to finance a trial.

The papers closest to mine in subject matter are Oster (2004), Miguel (2005), Johnson and Koyoma (2014), and Leeson and Russ (2018). Oster uses time series data to document a negative relationship between air temperatures and witch trials in Early Modern Europe, and argues that poor economic conditions prompt such trials. Unlike Oster, I focus on a single case study, Scotland, which had more centralised institutions than the rest of Europe for prosecuting witches. My data uncover a different result: positive economic shocks predict more witchcraft trials. I also provide empirical evidence for an explicit mechanism driving this result.

Miguel's (2005) study of Tanzania suggests a similar mechanism as Oster's: when rainfall is low, people kill unproductive members of society by blaming them for witchcraft. Tanzania, however, does not have the legal institutions that Scotland had for dealing with witchcraft accusations. Killings of alleged witches in Tanzania are much more decentralised, and are often carried out by family or community members without judicial restraint. In Scotland, sizable costs were incurred to ensure that legal procedure was carried out before a witch was executed, and it is not at all clear that alleged Scottish witches were economic burdens.

Johnson and Koyama (2014) investigate witchcraft trials in France between 1550 and 1700, and argue that increases in fiscal capacity strengthened rule of law, reducing the number of witchcraft trials. Again, Scottish 
trials were different from France's in this regard, since Scottish trials were more centralised, and followed rather strict judicial guidelines. My study addresses a different question: whether economic shocks caused witchcraft trials.

Leeson and Russ's (2018) study examines witch trials across Europe, and finds that non-market competition between Catholics and Protestants account for much of the variation in trials. I am interested in a different question, that of local elites. Focusing on a particular European country, Scotland, during the age of witch hunts, allows me to examine in detail institutional particulars. My explanation, moreoever, does not contradict Leeson and Russ's; it is possible that both religious competition and funding for trials mattered.

Because most Scottish witch suspects were women, this paper contributes to the literature on violence against women. ${ }^{1}$ Estimates find that intimate partner violence, and sexual violence against women, cost as much as $\$ 4.49$ trillion per year, or 5.3\% of world GDP (Fearon and Hoeffler, 2014). Causes of domestic violence, in particular, have been well-studied and include women's household bargaining power (Doss, 2013; Bloch and Rao, 2002) and emotional cues that prompt male spouses to act aggressively (Card and Dahl, 2011). In Early Modern Europe, women were viewed as inferior and corruptible beings, more naturally prone to witchcraft than men, which caused them to be hunted as witches (Rowlands, 2013). I find that positive weather shocks, and the resulting income boost to elites' coffers, can precipitate these acts of violence.

This paper contributes to the literature on historical witchcraft trials by using a panel dataset to study the impact of temperature on Scottish trials. Historians have postulated a number of factors that contributed to witch trials, including changing religious values (Levack, 2006), state expansion (Larner, 1981), and patriarchy (Apps and Gow, 2003). I offer another explanation: the costs of financing a trial must be sufficient.

Finally, a growing literature in political economics has examined persecutions (Jha, 2013; Voigtlander and Voth, 2012; Waldinger, 2010) . For instance, Anderson et al. (2017) find that bad weather shocks predict more Jewish expulsions from European cities between 1100 and 1800. The authors claim that these expulsions are driven by political economy concerns, as local rulers scapegoat Jews for economic woes. My story is also a political economy one, driven by the ability of local elites to finance a trial.

\section{Historical Background}

The Protestant Reformation consolidated itself in Scotland in 1560, when Edinburgh's Parliament formally rejected papal authority. Prior to the Ref-

\footnotetext{
1 Roughly $85 \%$ of Scottish witch suspects were women.
} 
ormation, witches were, at worst, seen as beings to be appeased, not persecuted. The Reformation changed this with its insistence on deliberate eradication of evil, thus making witchcraft a secular crime in 1563 with the Scottish Witchcraft Act (Cowan, 2008). The cultural reasons behind this are beyond this study's scope, though other authors have covered this in detail (Goodare, 2013; Roper, 1994; Smout, 1973).

Historical evidence suggests that central authorities, especially the Privy Council in Edinburgh, were able to exert some influence over proceedings, so that no local trials occurred without first going through Edinburgh. ${ }^{2}$ Local authorities were indeed content to have their trials sanctioned by central bureaucracy. According to a number of scholars, central control over witchcraft prosecutions was an important part of state building in Early Modern Scotland, a country that was otherwise difficult to govern (Dillinger, 2013; Larner, 1981). Although Larner (1981) finds that both elites and commoners believed in witches' magic, the former were content to use the latters' beliefs towards a secondardy objective: legal discipline, an important aspect of nation-building. $]^{3}$

There were five stages of most Scottish witch hunts (Goodare, 2002):

1. A witch is identified locally.

2. Evidence is gathered through local kirks (churches) and elites.

3. The Privy Council or parliament in Edinburgh reviews the evidence, and grants permission to local elites and witch hunters to set up a 'commission of judiciary' to try the accused.

4. The commission tries the witch.

5. The convicted witch is executed.

The bulk of expenses for the trial was incurred locally. The Privy Council was very interested in ensuring that proper judicial procedure was carried out, in order to prevent witch trials from descending into decentralised and unregulated lynchings.

The first stage, the identification of an alleged witch, happened locally: $\left.\right|^{4}$ A triggering event, such as a death in the family, would incite Scottish people to accuse neighbours of witchcraft. It usually took years before a neighbour's accusation of witchcraft would result in a formal complaint, a pattern consistent with the rest of Europe (Briggs, 1998). Another way to identify

2 Treason was the only other crime to enjoy such a level of central oversight (Larner, 1981).

3 The fact that educated elites believed in the Devil and his allegiance with witches is most apparent in King James's scholarly treatise, Daemonologie, which argues that witches should be killed.

4 An important exception, the 1590 North Berwick trials, started when King James accused witches of trying to sink his ship. However, even these trials relied on local identification of suspected witches. 
a witch was for already accused witches to name their co-conspirators, although such evidence was given less weight.

In the second stage, a confession was sought, and this stage often involved torture. Sleep deprivation was commonly used, and was very effective in obtaining confessions, since it led to hallucinations (Dudley and Goodare, 2013). This stage might involve local kirk (church) officials, who otherwise had a very limited role in witchcraft prosecutions. Local officials and elites had to ensure that the evidence collected during this stage was suitable for Edinburgh's vetting.

The third stage involved acquiring Privy Council or parliament's permission to set up a commission of judiciary, composed of local elites (lairds, burgesses, justices, etc.) to try a witch. As Levack (2008) says,

Most cases... were adjudicated by local authorities who petitioned the privy council or parliament for permission... These local commissioners then assembled an assize (jury) to determine innocence or guilt, which in most cases turned out to be the latter. (p. 4)

It was at this stage that the central government in Edinburgh got involved in local affairs. However, besides granting permission, the Privy Council and parliament usually did not intervene directly in local trials.

The trial itself, the fourth stage, relied on four types of evidence: confessions, neighbours' testimony, other witches' testimony, and The Devil's Mark. This last proof, either a visible blemish or insensitive spot on the body, was discovered by court examiners or professional witch-prickers. It was a sign of a witch having made a Satanic pact..$^{5}$ Once witchcraft was established, the witch was strangled at the stake until dead, and her body was subsequently burned.

To attain a more concrete analysis, I cite Paterson (2013), who uses case study evidence from Scottish witchcraft prosecutions to examine trial expenses. In 1596, when a day-labourer's wages were 40 pence per day (Gibson and Smout, 1994), it cost $£ 20$ to imprison a witch in Aberdeen.6 This paid for the accused's sustenance, as well as the costs of extracting a confession. Elites paid the amount; as Paterson documents, the bill was laid upon a laird's estate, a burgh council composed of merchant elites, or a town council comprised of local elites and magistrates. Although a witch's property was sometimes seized to pay part of the trial costs, most witches had little valuable property, and the bulk of expenses were paid by local elites:7

5 The pact was sexual in nature, culminating in a witches' orgy.

6 There were 240 pence in one Scottish pound.

7 Although these figures sketch an indication of the scale of the witchcraft trial, I am not aware of any figures of elite income, which limits my ability to compare the costs of a trial against a median elite's budget constraints. That being said, I would assume these 
The last Scottish witchcraft trial was in 1727, and witchcraft was removed from secular criminal offenses in 1736 . Historians investigating the decline and end of Scottish witch hunting have concluded that lawyers became less convinced about the validity of evidence in witchcraft cases: confessions under tortures were seen as questionable, and witch-pricking for the Devil's Mark was exposed as fraudulent (Wasser, 2008; Levack, 2008).

An example of a specific witchcraft trial helps to elucidate specifics. I take this case study from Larner (1981), who describes the stories of two women, of uncertain age, tried and executed for witchcraft in the town of Dumfries, in 1671. One of them, Janet Macmurdoch, had several accusors, including John Moor of Barlay, whose accusations dated from 1665, over Macmurdoch's unpaid rent. When John Moor impounded Janet's livestock, she cursed him, allegedly causing his child to subsequently die. Another accusor, John Murray of Laik, accused Janet of evil actions she committed in 1664, and Jean Sprot, another plaintiff, was cursed by Janet in the same year, causing Jean to suffer a strange disease. Clearly, it took a long time for accusations to come to fruition, in the form of a formal trial.

The jury consisted of small lairds and grand tenants, men of prominence, from a ten-mile radius around Dumfries. This assize had to travel over rough terrain, in order to preside over Janet's trial. This pattern reflects Scotland's rural character at the time: as Larner (1981) says, there were scattered villages instead of nucleated towns, a trend different from England's. On May 18, 1671, Janet Macmurdoch was executed, and her body burned.

\section{Data and Empirical Strategy}

\subsection{Empirical Strategy}

To test for the effects of temperature on witchcraft trials, I estimate the following specification:

$$
{\text { Witch } \text { Trial }_{i, t}=\beta \text { Shock }}_{i, t}+\delta_{i}+\eta_{t}+\epsilon_{i, t} .
$$

Here, Witch Trial $_{i, t}$ is either a dummy for whether or not a trial occurred, or a count for the number of witchcraft trials in county $i$ in year $t$.

$S h o c k_{i, t}$ is simply a temperature shock, where temperature is measured as a deviation from an average over the period 1961-1990. In my specifications, I use either a three-year, five-year, or ten-year moving average for temperature. The reason I use moving averages is because historians have documented that it took a long buildup for witchcraft suspicions to become full-blown accusations - sometimes as long as twenty years (Larner, 1981). To examine mechanisms related to agricultural commodities, I use

costs to have been significant, especially since Scottish lairds were not as wealthy as their English counterparts. 
Suitability $_{i} \times$ Price $_{t}$ for the shock, where Suitability is county $i$ 's suitability for the particular commodity, while Price $_{t}$ is its price on world markets in year $t$.

$\delta_{i}$ and $\eta_{t}$ are county and year fixed effects, respectively. I use these to control for omitted heterogeneity at the level of counties and time periods. I also report county-specific trends for robustness. The equation is estimated using OLS, and I cluster standard errors by county.

My identification strategy is based on the fact that temperature and world commodity prices are exogenous from a single county's point of view. A negative coefficient on $\beta$ implies that the shock negatively predicts unrest, while a positive coefficient $\beta$ means that the shock positively predicts unrest. In northern Europe, unlike tropical zones such as Africa, higher temperature are better for agriculture.

\subsection{Data}

I acquire witchcraft trial data from the online Survey of Scottish Witchcra$\mathrm{ft}$, which is available through the University of Edinburgh. The database was derived from previously existing printed data, and was enhanced through extensive archival research. Not all of those who were tried were executed: of the 305 cases we know the outcome for, 205 were executed, 52 were acquitted, and the rest were banished. However, while this sample gives an execution rate of $67 \%$, the Survey's researchers believe that the actual execution rate was much higher, since this sample mostly comprises trials at Edinburgh's justiciary court, which followed judicial procedure more rigidly than the vast majority of courts. The Survey offers wide coverage of the year and county of witchcraft trials, for 3,098 witch suspects. For additional documentation, please see the Survey's website $8^{8}$

Weather data for this period are scant, and the only panel data available for Europe are from Guiot and Corona (2010). These authors collect data from proxy sources, including ninety-five tree ring series, sixteen indexed climate series based on archives, ice-core series, and pollen series to construct grids of reconstructed growing-season (April to September) temperature for Europe from $900 \mathrm{AD}$ to today. I use geospatial software to match counties with their nearest grid points. The measured temperatures are based on deviations from the 1961-1990 average.

There is substantial evidence that warmer temperatures in northern Europe are better for agriculture (Olesen and Bindi, 2002). Studies of Early Modern northern Europe have shown that warmer temperatures predict lower wheat prices (Waldinger, 2014) and greater grain yield (Holopainen and Helama, 2009). Parry (1975), in particular, examined cereal cultivation in south-east Scotland from the late Middle Ages to the the eighteenth century, and found that colder temperatures substantially reduce yields. It is

\footnotetext{
8 http://www.shca.ed.ac.uk/Research/witches/
} 
therefore a sound assumption, for my analysis, that warmer temperatures improve agricultural conditions.

Scottish counties during this period look very different than they do today. Because no digital map of Early Modern Scottish counties is easily available, I constructed a map, using Geographic Information Software (QGIS), based on The Atlas of Scottish History to 1707. This gives me borders of counties that existed from 1563 to 1727, the years of my analysis.

In my specifications, I always control for population density, since this could impact trials. These data are from the History Database of the Global Environment (HYDE), and are available for the years 1500, 1600, 1700, 1710, 1720, and 1730.9 HYDE data are based on historical sources of population numbers. Because there are gaps in my data, I linearly interpolate between years, within counties, to construct a balanced panel.

Price data, in real amounts, are from the Allen-Unger database. These data were collected by Robert C. Allen and Richard W. Unger based on various sources, and contain the price of commodities in grams of silver per litre. I examine three commodities in my analysis: wool, herring, and oats. None of the price data come from Scotland, but rather from important trading posts and cities from around the world, like Massachusetts, London, and Paris. Based on the Atlas of Scottish History to 1707, I located and mapped Scotland's eight major trading ports: Leith, Glasgow, Bo'ness, Dundee, Ayr, Aberdeen, Burntisland, and Inverness. I then located the Allen-Unger location that is closest to Scotland in that particular time period, and used the commodity price from that port.

For wool, there is only one port for this period, "England." Herring price data are from Antwerp, "England," Frankfurt, Linkoping, and London. There are gaps in the herring price data, which I used linear interpolation to fill.

For oats, I use the price for London from 1550 to 1565, "Southern England" from 1566 to 1702, and Coutances for 1702 onwards.10 I also use oats price data with Gibson and Smout's (1994) price series for Scotland, which contains oats prices for Fife. Although oats prices from other regions are also available, Fife has the widest coverage. The correlation between the Allen-Unger oats price, and that from Gibson-Smout, is 0.2872, with corresponding $\mathrm{p}$-value 0.0058 . Clearly, the two price series for oats are wellcorrelated with each other.

Suitability for growing oats is from the Food and Agriculture Organization's Global Agro-Ecological Zones (GAEZ) database. I use the values for rainfed, low input oats suitability, and merge this with my map of Scotland. Because oats suitability may not identify where oats were actually grown historically, I also use cropland usage data from the History Database of the Global Environment for the year 1500. For pasture land, I acquire data from

\footnotetext{
${ }_{9}$ http://themasites.pbl.nl/tridion/en/themasites/hyde/

${ }^{10}$ There is a gap in this data for the year 1582, for which I use the oats price from Antwerp
} 
Ramankutty and Foley (1999), which helps me to identify the suitability for herding sheep. Finally, for herring, I use information from Rorke's (2005) article on the Scottish herring trade from 1470 to 1600; instead of a continuous suitability measure, I use an indicator, since Rorke describes whether or not a region caught herring for export.

Table 1 - Summary Statistics

\begin{tabular}{lccccc}
\hline Variable & N & Mean & Std. Dev. & Min & Max \\
\hline Main Results & & & & & \\
Witch Trials Count & 5,610 & 0.55 & 4.16 & 0 & 116 \\
Witch Trials Dummy & 5,610 & 0.10 & 0.30 & 0 & 1 \\
Temperature (3 year MA) & 5,610 & 0.16 & 0.42 & -1.11 & 1.83 \\
Temperature (5 year MA) & 5,610 & 0.16 & 0.35 & -0.81 & 1.73 \\
Temperature (10 year MA) & 5,610 & 0.16 & 0.29 & -0.55 & 1.30 \\
Population Density & 5,610 & 4,008 & 11,028 & 18.36 & 93,331 \\
& & & & & \\
Commodity Price Shocks & & & & & \\
Suitability × Price Wool (3 year MA) & 5,610 & 8.78 & 3.25 & 0.78 & 16.74 \\
Suitability × Price Wool (5 year MA) & 5,610 & 8.78 & 3.17 & 0.81 & 15.98 \\
Suitability × Price Wool (10 year MA) & 5,610 & 8.77 & 3.05 & 0.88 & 15.26 \\
Suitability × Price Herring (3 year MA) & 5,610 & 0.64 & 1.01 & 0 & 3.96 \\
Suitability × Price Herring (5 year MA) & 5,610 & 0.63 & 1.01 & 0 & 3.90 \\
Suitability × Price Herring (10 year MA) & 5,610 & 0.62 & 0.99 & 0 & 3.68 \\
Suitability × Price Oats (3 year MA) & 5,610 & 0.02 & 0.005 & 0.009 & 0.04 \\
Suitability × Price Oats (5 year MA) & 5,610 & 0.02 & 0.005 & 0.01 & 0.04 \\
Suitability × Price Oats (10 year MA) & 5,610 & 0.02 & 0.005 & 0.01 & 0.03 \\
& & & & & \\
Compliers & & & & & \\
Distance from Edinburgh: above median & 34 & 0.5 & 0.5 & 0 & 1 \\
Times of crisis: indicator & 5,610 & 0.05 & 0.23 & 0 & 1 \\
Justices of the Peace: above median & 33 & 0.48 & 0.5 & 0 & 1 \\
Distance from a Port: above median & 34 & 0.5 & 0.5 & 0 & 1 \\
\hline
\end{tabular}

County-level fixed effects mean that I do not need to control for timeinvariant county characteristics. However, I interact variables, such as distance from Edinburgh and justices of the peace, with my independent variable to test for heterogenous responses of trials to weather shocks. These are above-median indicators. For example, if distance from Edinburgh is greater than median, I code this as a 1, and as a 0 otherwise. I acquire justices of the peace data from the Atlas of Scottish History to 1707; this is the average number of justices over the period 1587 to 1663 , when data is available.

Summary statistics for my dependent variables, shocks of interest, and county characteristics are shown in Table 1. I also provide a map of the total number of witchcraft trials over this period in Figure 1. As can be seen, Edinburgh and East Lothian (Haddington) had the most intense witch-hunting. 
In Figure 2, I plot the 5 year moving average of temperature against witchcraft trials, from 1563 to 1727 . The horizontal line, in the graph, is the mean value of the 5-year moving average of temperature over this period. As can be seen, when the temperature variable is below its mean, witchcraft trials are less likely to occur. I exploit this variation as part of my identification strategy ${ }^{11}$

Figure 1 - Total Number of Witchcraft Trials, 1563-1727

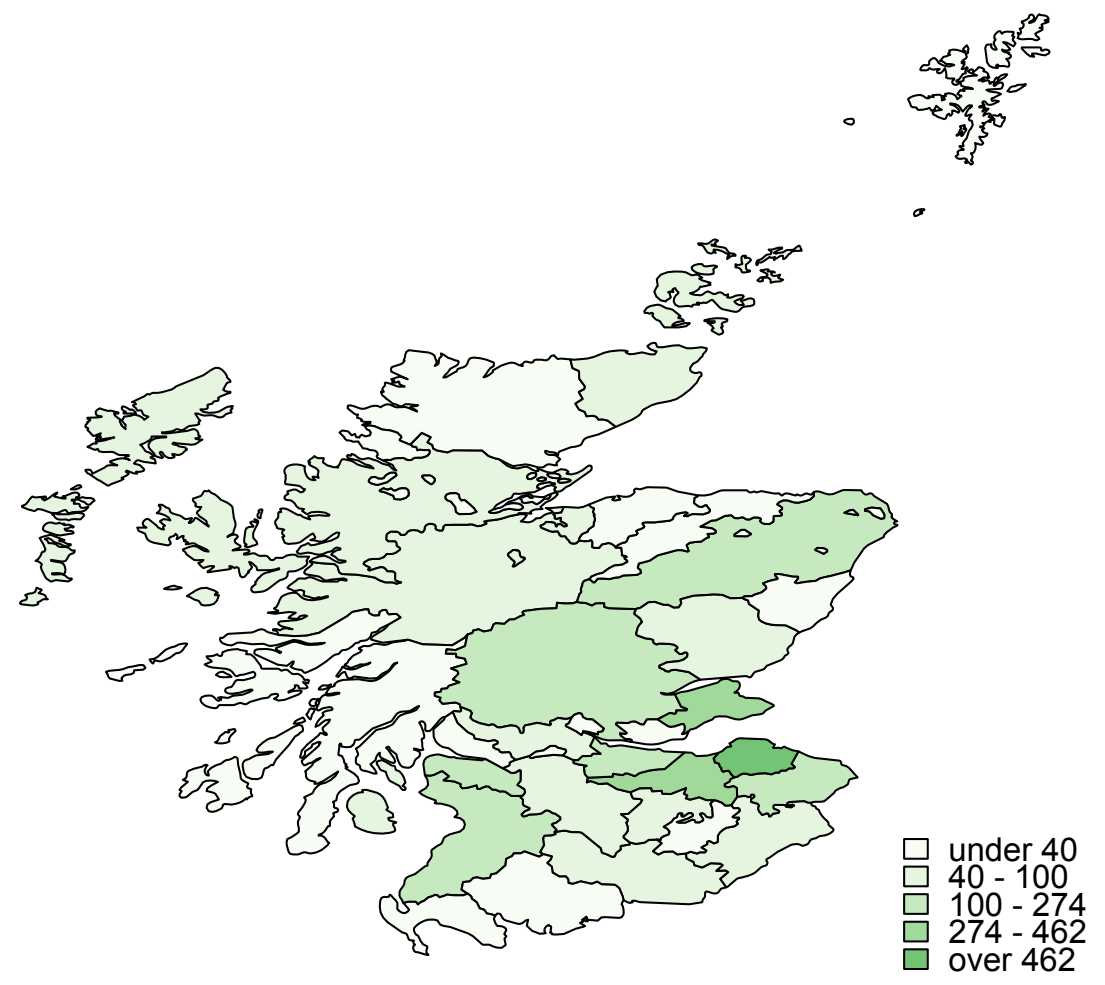

\footnotetext{
${ }^{11}$ In the appendix, I include figures for the 3-year and 10-year moving averages of temperature, plotted against witchcraft trials. These are Figures A1 and A2.
} 
Figure 2 - Total Number of Witchcraft Trials against Temperature (5 Year Moving Average), 1563-1727

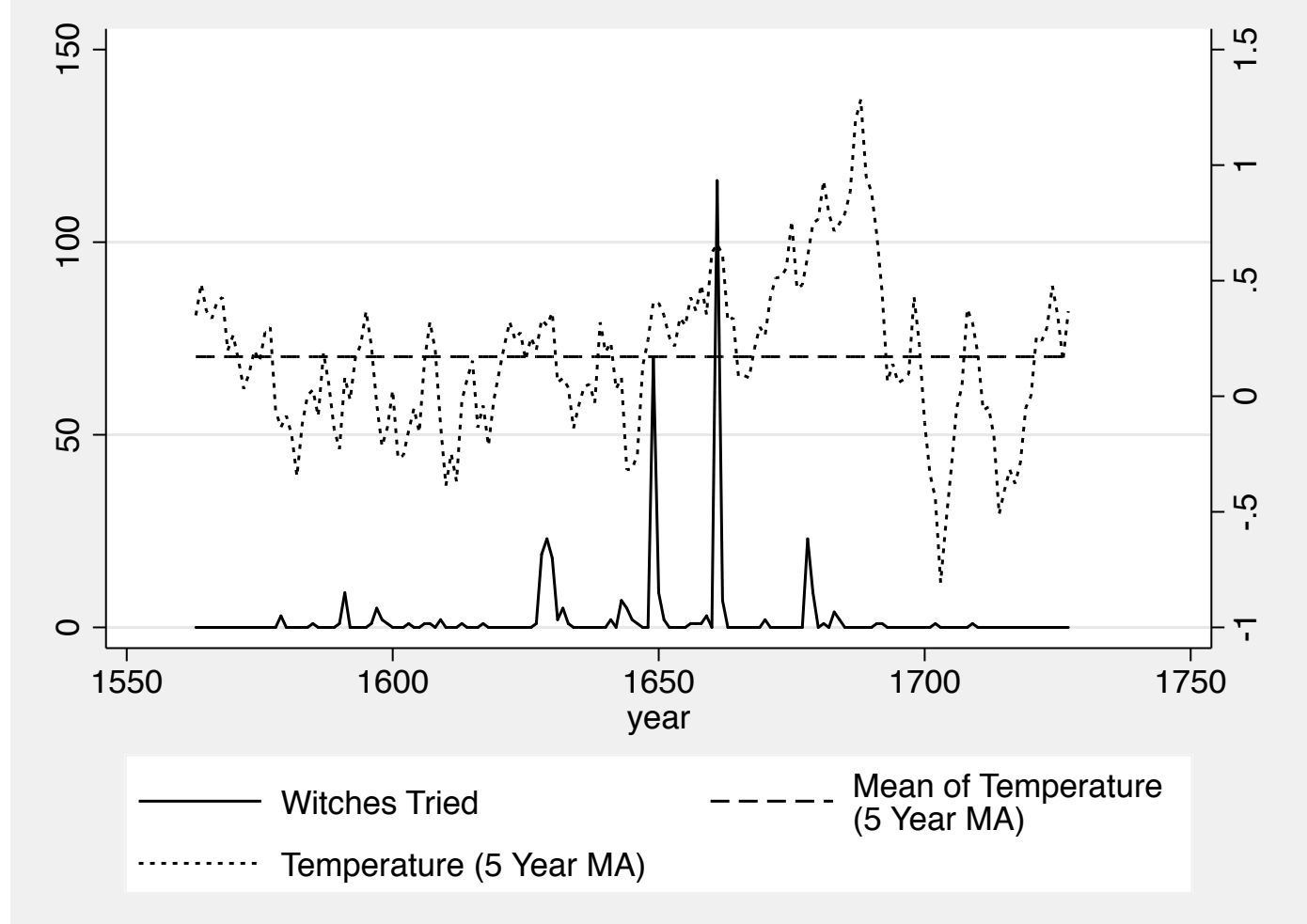

\section{Results}

\subsection{Main Results}

In Table 2, I report my main results for witch trials from 1563 to 1727, using three different moving averages for 3 years, 5 years, and 10 years. In these regressions, I report two sets of standard errors. First, I report standard errors that cluster at the county level. Second, I report Conley (1999) standard errors, which account for spatial correlation, for a radius up to $100 \mathrm{~km}$ from the center of a county, and arbitrary temporal correlation, up to 10 lags. As can be seen, positive shocks to temperature predict more trials, and the results are generally significant. Not all columns report significant results; Column (1), in particular, shows that, regardless of the reported standard errors, a 3-year moving average of temperature does not significantly predict witchcraft trials; that being said, the magnitude of the effect is large, since according to the coefficient estimate, a standard deviation rise in the temperature variable causes a 0.05 standard deviation rise in trials. These magnitudes are also reflected in other columns. For example, in column (2), a standard deviation increase in temperature causes a 0.06 standard 
deviation increase in trials. In column (5), a standard deviation increase in temperature causes a 0.14 standard deviation increase in the probably of a trial, or $4.06 \%$. All regressions control for county-level population density, which might also predict trials.

Table 2 - Effect of Temperature Shocks on Witchcraft Trials

\begin{tabular}{|c|c|c|c|c|c|c|}
\hline & $(1)$ & $(2)$ & (3) & (4) & (5) & (6) \\
\hline Dependent variable: & Count & Count & Count & Dummy & Dummy & Dummy \\
\hline \multirow[t]{3}{*}{ Temperature ( 3 year MA) } & .548 & & & .104 & & \\
\hline & $(.504)$ & & & $(.046)^{* *}$ & & \\
\hline & {$[.485]$} & & & {$[.037]^{* * *}$} & & \\
\hline \multirow[t]{3}{*}{ Temperature (5 year MA) } & & .711 & & & .116 & \\
\hline & & $(.341)^{* *}$ & & & $(.040)^{* * *}$ & \\
\hline & & {$[.345]^{* *}$} & & & {$[.042]^{* * *}$} & \\
\hline \multirow[t]{3}{*}{ Temperature (10 year MA) } & & & .805 & & & .161 \\
\hline & & & $(.499)$ & & & $(.071)^{* *}$ \\
\hline & & & {$[.409]^{* *}$} & & & {$[.055]^{* * *}$} \\
\hline County FE & Yes & Yes & Yes & Yes & Yes & Yes \\
\hline Year FE & Yes & Yes & Yes & Yes & Yes & Yes \\
\hline Counties & 34 & 34 & 34 & 34 & 34 & 34 \\
\hline No. of observations & 5,610 & 5,610 & 5,610 & 5,610 & 5,610 & 5,610 \\
\hline
\end{tabular}

These effects can be favourably compared to Hsiang et al's (2013) metaanalysis of the literature on climate and conflict, which finds that a standard deviation increase in temperature causes a $4 \%$ median increase in interpersonal violence, and a $14 \%$ increase in intergroup violence, across studies. Hsiang and his coauthors classify Tanzanian witch killings as "Personal Violence and Crime," and claim that these median figures are substantial, lending support to my results on Scottish witch trials.

\subsection{Robustness}

It is possible that I am not accounting for time-varying, county-specific factors that might affect witchcraft prosecutions. I thus repeat the analysis using county-specific time trends in Table 3. The results are still positive, large, and generally significant: for example, in column (6), a standard deviation increase in temperature (10 year MA) causes a 0.19 standard deviation increase in the probability of a trial, or $5.63 \%$. As in Table 2, the results that are not significant are found in Columns (1) and (3); in these cases, the weather shock does not predict the intensity of trials with significance, though the resutls are of a favourable magnitude.

In Table 4, I conduct additional robustness checks by changing the empirical specification. In Columns (1)-(3), I run a logistic regression analysis, and in columns (4)-(6), I use $\ln ($ trials +1$)$ as my dependent variable. Results are still large and significant. 
Table 3 - Main Results with County-Specific Trends

\begin{tabular}{|c|c|c|c|c|c|c|}
\hline & (1) & (2) & (3) & (4) & (5) & (6) \\
\hline Dependent variable: & Count & Count & Count & Dummy & Dummy & Dummy \\
\hline Temperature ( 3 year MA) & $\begin{array}{c}.619 \\
(.571)\end{array}$ & & & $\begin{array}{l}.110^{* *} \\
(.049)\end{array}$ & & \\
\hline Temperature (5 year MA) & . & $\begin{array}{l}.850^{* *} \\
(.374)\end{array}$ & & & $\begin{array}{l}.126^{* * *} \\
(.036)\end{array}$ & \\
\hline Temperature (10 year MA) & . & & $\begin{array}{c}.962 \\
(.601)\end{array}$ & & & $\begin{array}{l}.194^{* *} \\
(.084)\end{array}$ \\
\hline County FE & Yes & Yes & Yes & Yes & Yes & Yes \\
\hline Year FE & Yes & Yes & Yes & Yes & Yes & Yes \\
\hline County-Specific Trends & Yes & Yes & Yes & Yes & Yes & Yes \\
\hline Counties & 34 & 34 & 34 & 34 & 34 & 34 \\
\hline No. of observations & 5,610 & 5,610 & 5,610 & 5,610 & 5,610 & 5,610 \\
\hline
\end{tabular}

Table 4 - Main Results: Different Specifications

\begin{tabular}{lcccccc}
\hline & $(1)$ & $(2)$ & $(3)$ & $(4)$ & $(5)$ & $(6)$ \\
Dependent variable: & Dummy & Dummy & Dummy & $l n$ & $\ln$ & $\ln$ \\
\hline Temperature (3 year MA) & $.012^{*}$ & & & $.149^{*}$ & & \\
& $(.008)$ & & & $(.076)$ & & \\
Temperature (5 year MA) &. & $.024^{* * *}$ & & & $.176^{* * *}$ \\
& & $(.009)$ & & & $(.061)$ & \\
Temperature (10 year MA) &. & & .004 & & & $.220^{* *}$ \\
& & & $(.011)$ & & & $(.101)$ \\
Robustness Check: & Logit & Logit & Logit & Dep Var & Dep Var & Dep Var \\
County FE & Yes & Yes & Yes & Yes & Yes & Yes \\
Year FE & Yes & Yes & Yes & Yes & Yes & Yes \\
\hline Counties & 34 & 34 & 34 & 34 & 34 & 34 \\
No. of observations & 5,610 & 5,610 & 5,610 & 5,610 & 5,610 & 5,610 \\
\hline $\begin{array}{l}\text { Notes: Standard errors, clustered at the county level, are reported in parentheses. Significance levels are } \\
\text { (*** }<\end{array}$
\end{tabular}

As an additional check, I exclude trials prior to 1610. This is for two reasons. First, King James set off a national witch panic in 1590 when he accused witches of trying to kill him by sinking his ship. Thus, witch trials in 1590 were not due to local factors. Furthermore, Goodare (2002) claims that autonomous local trials, without central approval, occurred prior to 1610. These trials were conducted in regality courts, private courts that landlords held to settle disputes, and so were not as costly as establishing a commission of justiciary. Results are shown in Table 5. The results are significant, and larger than before, as I would expect. For example, in column (1) a standard deviation increase in temperature (3 year MA) causes a 0.11 standard deviation increase in trials. Favourable weather continues to cause more witchcraft trials.

Furthermore, it is possible that political events in the 1650s to 1660s are driving these results. As I discuss later, this period involved English occupation of Scotland, and it is possible that lairds were forced to demon- 
Table 5 - Excluding Years Prior to 1610

\begin{tabular}{|c|c|c|c|c|c|c|}
\hline & (1) & (2) & (3) & (4) & (5) & (6) \\
\hline Dependent variable: & Count & Count & Count & Dummy & Dummy & Dummy \\
\hline \multirow[t]{2}{*}{ Temperature ( 3 year MA) } & $1.12^{* *}$ & & & $.196^{* * *}$ & & \\
\hline & $(.545)$ & & & $(.059)$ & & \\
\hline \multirow[t]{2}{*}{ Temperature ( 5 year MA) } & . & $1.30^{* * *}$ & & & $.228^{* * *}$ & \\
\hline & & $(.413)$ & & & $(.059)$ & \\
\hline \multirow[t]{2}{*}{ Temperature (10 year MA) } & . & & $1.50^{* * *}$ & & & $.290^{* * *}$ \\
\hline & & & $(.526)$ & & & $(.095)$ \\
\hline County FE & Yes & Yes & Yes & Yes & Yes & Yes \\
\hline Year FE & Yes & Yes & Yes & Yes & Yes & Yes \\
\hline Counties & 34 & 34 & 34 & 34 & 34 & 34 \\
\hline No. of observations & 4,012 & 4,012 & 4,012 & 4,012 & 4,012 & 4,012 \\
\hline
\end{tabular}

strate subservience to their English overlords by, among other tasks, trying witches. ${ }^{12}$ I therefore repeat the analysis in Table 2 , by excluding the $1650 \mathrm{~s}$ and 1660s from my analysis. The results, reported in Table 6, remain large and significant. For instance, in column (6), a standard deviation increase in the temperature shock causes a $5 \%$ increase in witch trials.

Table 6 - Excluding the 'Turbulet' 1650s to 1660s

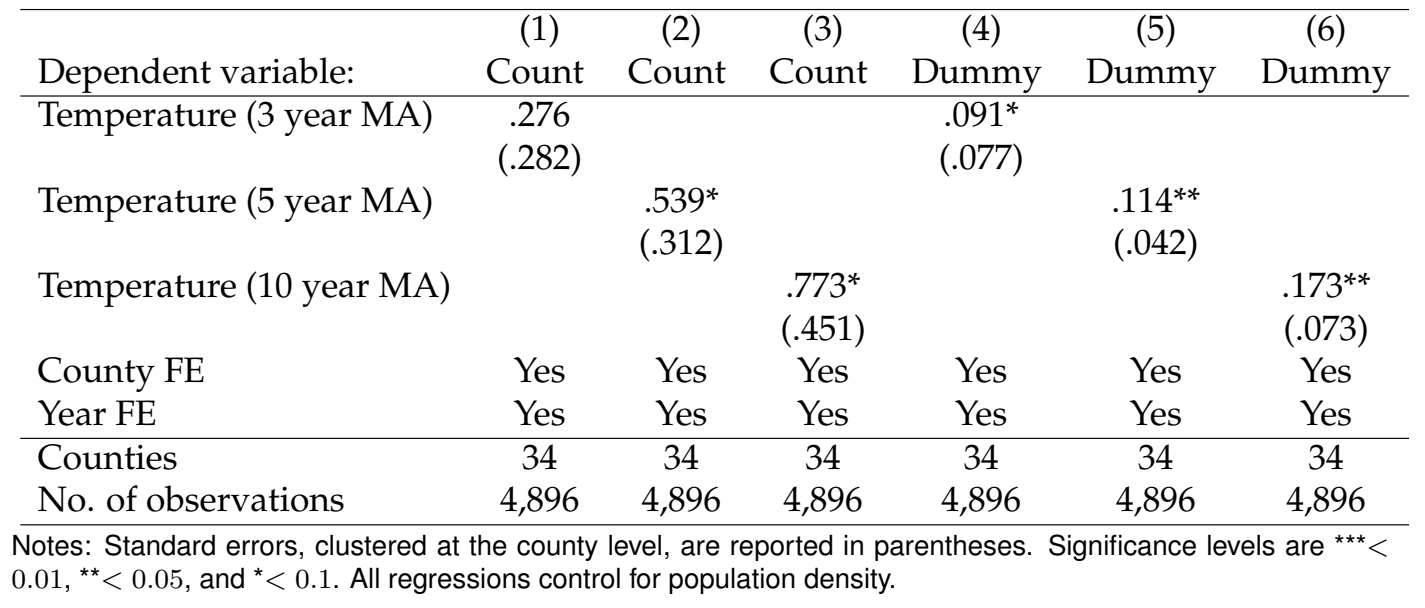

My crucial identifying assumption is that weather is unrelated to unobservables that could bias my estimates. To determine if this is in fact the case, I perform a placebo test in Table 7, replacing current moving-average weather shocks with future moving-average weather shocks (one year forward). If my identification is sound, then there is no reason that future weather should predict current witch trials. As my results show, there is no significant relationship between witch trials and future weather, and the coefficient estimates are smaller than those for my main results. For example,

\footnotetext{
12 Indeed, my data show that 384 witches were tried in the 1650s, and 647 in the 1660s, for a total of 1,031 .
} 
in column (2), a standard deviation increase in the five-year moving average predicts only a 0.01 standard deviation increase in trials. Compare this to column (2) in Table 2, with a 0.06 standard deviation increase in trials predicted. This supports my identification strategy.

Table 7 - Future Weather Shocks (One Year Forward) and Current Witch Trials

\begin{tabular}{|c|c|c|c|c|c|c|}
\hline & (1) & (2) & (3) & (4) & (5) & $\begin{array}{c}\text { (6) } \\
\text { (1) }\end{array}$ \\
\hline Dependent variable: & Count & Count & Count & Dummy & Dummy & Dummy \\
\hline Temperature ( 3 year MA) & $\begin{array}{l}-.277 \\
(.297)\end{array}$ & & & $\begin{array}{c}.048 \\
(.068)\end{array}$ & & \\
\hline Temperature (5 year MA) & . & $\begin{array}{c}.158 \\
(.415)\end{array}$ & & & $\begin{array}{c}.085 \\
(.061)\end{array}$ & \\
\hline Temperature (10 year MA) & . & & $\begin{array}{c}.417 \\
(.404)\end{array}$ & & & $\begin{array}{c}.120 \\
(.071)\end{array}$ \\
\hline County FE & Yes & Yes & Yes & Yes & Yes & Yes \\
\hline Year FE & Yes & Yes & Yes & Yes & Yes & Yes \\
\hline Counties & 34 & 34 & 34 & 34 & 34 & 34 \\
\hline No. of observations & 5,610 & 5,610 & 5,610 & 5,610 & 5,610 & 5,610 \\
\hline
\end{tabular}

An alternate explanation for these patterns is greed: namely, witchcraft suspects had possessions that neighbours and the Crown wished to seize, and these possessions increased in value during beneficial years. There were a handfull of cases like this - notably, there were seven high-status women who were accused by heavily indebted men with property disputes (Yeoman, 2002). However, most such prosecutions failed, and the vast majority of witchcraft suspects were low-status women with no valuable property. Of the 316 witch suspects in my dataset whose socioeconomic status is known, only 9 are classified as either "Lairds/Baron" or "Nobility/Chiefs". Given the time and resources it took to try witches, historians do not believe that witchcraft trials were driven by greed (Goodare, 2010). Early Modern Scots, including educated elites, believed strongly in witchcraft, and were willing to take concrete measures to extirpate evil.

In Table 8, I briefly consider simple lagged temperature shocks, since my hypothesis depends crucially on the buildup of elite resources prior to a trial. In other words, elites need to accumulate resources over time in order for trials to occur, while there is unsatisfied demand. Although only column (4) in Table 4.7 is significant, all specifications yield positive and large coefficients. For example, column (2) shows that a standard deviation increase in temperature causes a 0.08 standard deviation increase in trials.

My hypothesis of a supply-side constraint is further demonstrated through a political incident: the 1660 end of Republican occupation of Scotland. After the English republicans left Scotland to its own devices, there was an outbreak of witchcraft trials. According to my data, only 2 trials were held in 1660. From 1661-1662, there were 612 witches prosecuted. Although this was a political event, it nonetheless supports my resource constraint theory 
Table 8 - Effect of Temperature Shocks on Witchcraft Trials: One Year Lags

(1)

(2)

(3)

(4)

\begin{tabular}{lcccc} 
Dependent variable: & Count & Count & Dummy & Dummy \\
\hline Temperature & .093 & .524 & .067 & $.123^{* *}$ \\
& $(.372)$ & $(.367)$ & $(.055)$ & $(.060)$ \\
County FE & Yes & Yes & Yes & Yes \\
Year FE & Yes & Yes & Yes & Yes \\
\hline Counties & 34 & 34 & 34 & 34 \\
No. of observations & 5,610 & 4,012 & 5,610 & 4,012 \\
\hline
\end{tabular}

Notes: Standard errors, clustered at the county level, are reported in parentheses. Significance levels are ${ }^{\star * *}<$ $0.01,{ }^{*}<0.05$, and ${ }^{*}<0.1$. All regressions control for population density.

of Scottish witch trials.

Finally, in Table A1 in the appendix, I regress witchcraft trials on lagged trials, to determine whether there is persistence in trials. Although the previous two years appear to significantly predict trials, trials in general do not appear to be significant. A standard deviation increase in the occurrence of a trial in the previous year causes a .174 rise in the probability of a trial in the current year. Across specifications, the coefficients are comparable; this makes sense, given that the temperature shocks are moving averages that are strongly correlated with each other (a 3-year moving average is strongly correlated with a 5-year one, for example).

I have documented a robust relationship between beneficial temperatures and witchcraft prosecutions. This fits well with the observations that local elites required resources to conduct witchcraft prosecutions. It also supports my theoretical prediction that years of higher income should experience more trials.

\subsection{Compliers}

In Table 9, I interact the 5 year moving average weather shock with various compliers. First, I examine whether distance from Edinburgh had an impact. Those wishing to try a witch had to seek the Privy Council or parliament's permission in Edinburgh; in my model, this proxies for a higher marginal cost of conducting a trial. Indeed, I find that a greater distance from Edinburgh (higher than median) attenuates the impact of the shock on trials.

I then determine whether having more justices of the peace has an impact. Data on justices of the peace are available for every county except Cromarty, and therefore my sample size is slightly smaller. More justices of the peace implies a lower marginal cost of conducting a trial, since there is some legal state capacity available to try a witch. Indeed, this amplifies the impact of the shock.

To get a sense of the marginal benefit of prosecuting a witch, I infer that 
Table 9 - Effect of Temperature Shocks on Witchcraft Trials: One Year Lags

\begin{tabular}{|c|c|c|c|c|}
\hline Dependent variable: witch trials & (1) & $(2)$ & (3) & $(4)$ \\
\hline \multirow[t]{2}{*}{ Temperature (5 year MA) } & $.194^{* * *}$ & .198 & .270 & $2.045^{* *}$ \\
\hline & $(.052)$ & $(.539)$ & $(.216)$ & $(.804)$ \\
\hline \multirow[t]{2}{*}{ Temperature $\times$ interaction } & $-.060^{* * *}$ & $.813^{*}$ & $10.09^{*}$ & $-1.043^{* *}$ \\
\hline & $(.021)$ & $(.472)$ & $(5.42)$ & $(.482)$ \\
\hline Interacted variable: & $\begin{array}{c}\text { Distance from } \\
\text { Edinburgh }\end{array}$ & $\begin{array}{l}\text { Justices of } \\
\text { the Peace }\end{array}$ & $\begin{array}{l}\text { Political } \\
\text { Crises }\end{array}$ & $\begin{array}{c}\text { Distance from } \\
\text { a Port }\end{array}$ \\
\hline County FE & Yes & Yes & Yes & Yes \\
\hline Year FE & Yes & Yes & Yes & Yes \\
\hline Counties & 34 & 33 & 34 & 34 \\
\hline No. of observations & 5,610 & 5,445 & 5,610 & 5,610 \\
\hline
\end{tabular}

during times of national political crisis, the marignal benefit increases - i.e., it is dangerous to let witches roam during these times. I use Levack (2008) to identify five periods of political instability. These are as follows: In 1590-91, James I was fending off a series of rebellions; In 1597, there was a largescale quarrel between church and the state; In 1643-44, a radical group of presbyterians, the covenanters, consolidated political power in Scotland; In 1649-50, some covenanters fought English military efforts to occupy Scotland; Finally, in 1661-1662, the covenanters were displaced by royal power. I code each of these years as a ' 1 ', and a zero otherwise, and then interact this with the weather shock. Clearly, times of crisis exacerbate the impact of this shock on trials. This corresponds to an increase in the marginal benefit, leading to more witch trials.

Finally, I examine distance from the nearest trade port. Counties further from trading ports have less access to alternate sources of income. If this is greater than median, I indicate this as a ' 1 ', with a zero otherwise. This is intended to capture $y$, the value of income. According to my model, the smaller this income is, the less likely a trial is to occur. Indeed, a higher distance from a port attenuates the impact of the shock on witch trials, lending support to my hypothesis.

\subsection{Mechanisms}

Because local elites, such as lairds and burgesses, were responsible for the time and money involved in carrying out witch trials, I expect that positive shocks to their income would lead to more witchcraft trials. Specifically, as a proxy variable for elite income, price shocks to export-heavy, taxable commodities like herring and wool should have an impact on trials, while price shocks to Scotland's main subsistence commodity, oats, should have no effect.

Historical evidence states that local elites derived income not only from peasant rents, but also from exports. Customs duties were levelled on goods 
Table 10 - Effect of Wool and Herring Shocks on Witch Trials

\begin{tabular}{|c|c|c|c|c|c|c|}
\hline Price Shock: & $\begin{array}{c}(1) \\
\text { Wool }\end{array}$ & $\begin{array}{c}(2) \\
\text { Wool }\end{array}$ & $\begin{array}{c}\text { (3) } \\
\text { Wool }\end{array}$ & $\begin{array}{c}(4) \\
\text { Herring }\end{array}$ & $\begin{array}{c}(5) \\
\text { Herring }\end{array}$ & $\begin{array}{c}(6) \\
\text { Herring }\end{array}$ \\
\hline 3 year MA & $\begin{array}{l}.198^{* *} \\
(.092)\end{array}$ & & & $\begin{array}{l}.019^{* *} \\
(.009)\end{array}$ & & \\
\hline 5 year MA & . & $\begin{array}{l}.186^{* *} \\
(.087)\end{array}$ & & & $\begin{array}{l}.018^{* *} \\
(.008)\end{array}$ & \\
\hline 10 year MA & . & & $\begin{array}{l}.236^{* *} \\
(.103)\end{array}$ & & & $\begin{array}{l}.015^{* *} \\
(.007)\end{array}$ \\
\hline County FE & Yes & Yes & Yes & Yes & Yes & Yes \\
\hline Year FE & Yes & Yes & Yes & Yes & Yes & Yes \\
\hline Counties & 34 & 34 & 34 & 34 & 34 & 34 \\
\hline No. of observations & 5,610 & 5,610 & 5,610 & 5,610 & 5,610 & 5,610 \\
\hline
\end{tabular}

exiting Scotland, helping to fill the coffers of burgesses and lairds through customs farming. Evidence from Gowrie and Aberdeen also suggests that tenants paid landlords rents in the form of surplus agricultural produce, which landlords then sold to merchants to buttress their income (Young, 2007; Whyte, 1986). Furthermore, many elites (burgesses) of royal burghs and burghs of barony were themselves merchants, who relied on export income to exert local political and economic power (Brown, 1992; Smout, 1973). Based on data from the Atlas of Scottish History to 1707, I was able to identify two of the most common exports: wool, and herring. Based on a 1614 survey of exports from the Atlas, wools and wool products composed about $15 \%$ of total exports, while herring composed $13 \%$ of total exports. Fells (timber) is the only commodity that comprises a larger percentage of exports (21\%), but based on customs receipts from 1595 to 1599, wool and herring were taxed at a higher rate than fells. I therefore focus on wool and herring as examples of export-heavy, taxable commodities.

Scotland's main subsistence commodity, oats, was not exported much at all. Oats comprise $0.4 \%$ of total exports, based on the 1614 survey. Oats' short growing season combined with their nutritious content made them a staple diet among Scots (Smout, 1973). Therefore, although it was an important crop, oats do not contribute significantly to elite income, and therefore should not impact witch trials.

My reduced form relationship between weather and witch trials requires some discussion here. Warm temperatures in Scotland were important for growing oats, but also for producing wool and catching herring. Veterinary studies show that sheep shear better when temperatures are warm, and they can die or fall ill under inclement conditions (Glass and Jacob, 1991; Torell et al., 1969). With regards to herring, a common method of storage at the time was salting (Rorke, 2005), which works better under warmer temperatures. It is also more likely for fishing boats to sail when the weather is good. 
A limitation of this study is that hardly any systematic agricultural yield data have survived from this period. This means that I cannot directly test for the impact of temperatures on agricultural productivity. However, Young (2007), while admitting that "[t]he survival from this period of systematic recordings of the yields obtained on Scottish farms is extremely rare," nonetheless manages to unearth data from one particular farm in the Carse of Gowrie, over a 23 year period (1673-95). She examines wheat, bere, oats, and pease yields in the farm, and concludes that of all the factors that affect output, climate and weather are the most important. Warmer climates and temperatures are better suited to crop production in Scotland than colder spells, which would destroy crops. Given this historical evidence, combined with the scientific studies previously mentioned I can be more confident in establishing the link between warm weather and favourable agricultural output in early modern Scotland.

In Table 10, I show the regressions for wool/herring price shocks and witch trials. Total witch trials is the outcome variable. Clearly, higher prices of both commodities lead to more trials. For example, in column (1), a standard deviation increase in the wool price shock ( 3 year MA) increases trials by 0.15 standard deviations. In column (4), a standard deviation increase in the herring price shock ( 3 year MA) increases trials by 0.10 standard deviations. In the Appendix, Table A2, I also control for the temperature shock, and interact the temperature shock with the wool or herring price shock; the results are generally preserved, but slightly weaker. In particular, the temperature shock loses signifiance; this aligns well with my theoretical predictions, since if price shocks are the mechanism through which elites gain income to try witches, then temperature works through price shocks to affect witchcraft trials - meaning that temperature shocks would lose significance. The Appendix analysis shows that the herring and wool price shocks retain their statistical significance.

Table 11 - Effect of Oats Shocks on Witch Trials

\begin{tabular}{lccccccccc}
\hline & $(1)$ & $(2)$ & $(3)$ & $(4)$ & $(5)$ & $(6)$ & $(7)$ & $(8)$ & $(9)$ \\
\hline 3 year MA shock & -.013 & & & .011 & & & -.0006 & & \\
& $(.011)$ & & & $(.013)$ & & & $(.0006)$ & & \\
5 year MA shock &. & -.012 & & & .008 & & & -.0004 & \\
& & $(.010)$ & & & $(.011)$ & & & $(0.0004)$ & \\
10 year MA shock &. & & -.011 & & & .008 & & & $-.001^{*}$ \\
& & & $(.009)$ & & & $(.011)$ & & & $(.0006)$ \\
County FE & Yes & Yes & Yes & Yes & Yes & Yes & Yes & Yes & Yes \\
Year FE & Yes & Yes & Yes & Yes & Yes & Yes & Yes & Yes & Yes \\
\hline Counties & 34 & 34 & 34 & 34 & 34 & 34 & 34 & 34 & 34 \\
No. of observations & 5,610 & 5,610 & 5,610 & 5,610 & 5,610 & 5,610 & 2,890 & 2,822 & 2,652 \\
\hline
\end{tabular}

Notes: Standard errors, clustered at the county level, are reported in parentheses. Significance levels are ${ }^{* * *}<$ $0.01,{ }^{* *}<0.05$, and ${ }^{*}<0.1$. All regressions control for population density.

In Table 11, I regress witch trials on oat price shocks. In columns (1)-(3), I interact the world oats price with the FAO data for oats suitability. There 
is no significant effect, although the coefficient estimates' sizes are comparable to those for herring and wool. In column (3), a standard deviation increase in the oat price shock reduces trials by 0.13 standard deviations. The coefficient estimates are negative, which could suggest the following story: peasants who grow and sell oats blame witches when oat prices are low. Although this is plausible, there is no historical evidence to support it, and at any rate, the coefficients are insignificant: even if peasants complain about witches, elites need the resources to prosecute. In columns (4)-(6), I interact the world oats price with HYDE data for cropland usage, and again find an insignificant impact, although it is now positive, further indicating that the oats price does not robustly predict trials. The effect is still sizable - for instance, in column (4), a standard deviation increase in the oats shock predicts a 0.09 standard deviation increase in witchcraft trials - however, given the overall insignificance, and the fact that this insignificance is robust across specifications, I can conclude that oats shocks do not predict witch trials. In columns (7)-(9), I use Gibson and Smout's (1994) oats price data for Fife, and again find an overall insignificant effect. However, in column (9), the 10-year-moving-average is slightly significant, and the coefficient estimate is large: a standard deviation increase in the shock reduces trials by 0.18 standard deviations. Nonetheless, the overall impact of oats prices on trials appears insignificant.

There is, additionally, anecdotal evidence that spending on other public goods increased following favourable weather. The town of Aberdeen, for example, was unique in its retention of a large Justice of the Peace Court, which tried crimes like fornication and adultery. Running the court was fairly expensive and, according to DesBrisay (1986),

The forces of nature could clearly influence the court's work: in 1697, when... poor weather and serious food shortages led to disease and high mortality, the justice court sat only thirteen times... it seems likely that backlogs of cases occasionally built up. (p. 81)

It therefore makes sense that witch trials would increase following favourable temperature.

\section{Conclusion}

Persecution of populations is not always a disorganised, unruly affair. Events like the Khmer Rouge killings, East Timorese massacres, and Rwandan genocide were all planned and organised by elites. Similarly, Early Modern Scottish witchcraft trials required local elites' time and material resources.

In this paper, I have shown that positive weather shocks caused more witchcraft trials in Early Modern Scotland. During such good times, local elites had more resources to devote to witch prosecutions. Consistent with 
this, I find that positive price shocks to export-heavy, taxable commodities, herring and wool, caused more trials, while shocks to oats, Scotland's main subsistence commodity, did not.

A further question raised by this paper is that of policy: namely, how can we prevent persecution, when elites finance it? Based on my findings, the answer might be to target the export of goods that elites derive wealth and power from ${ }^{13}$ Indeed, such sanctions are used against states like North Korea and Iran ostensibly for this purpose (Elliot, 1998; Marinov, 2005). An Early Modern 'omnipotent economic planner' wishing to limit witchcraft trials would therefore sanction the export of wool and herring from Scotland. Pertinent economic and political actors may react unexpectedly to sanctions; however, the policy implications of this approach are worth examining in future research.

\footnotetext{
${ }^{13}$ This abstracts from general equilibrium concerns. Sanctions can, after all, harm even
} persecuted populations by denying them of food, medicine, and income. 


\section{References}

Abadie, A., Gardeazabal, J., 2003. The Economic Costs of Conflict. American Economic Review 93(1), 113-132.

Acemoglu, D., Chaves, I. N., Osafo-Kwaako, P., Robinson, J. A., 2014. Indirect Rule and State Weakness in Africa: Sierra Leone in Comparative Perspective. NBER Working Paper No. 20092.

Acemoglu, D., Hassan,T., Robinson, J.A., 2011. Social Structure and Development: A Legacy of the Holocaust in Russia. Quarterly Journal of Economics 126 (2), 895-946.

Anderson, R. W., Johnson, N. D., Koyama, M., 2017. Jewish Persecutions and Weather Shocks: 1100-1800. Economic Journal 127 (602), 924-958.

Angrist, J. D., Kugler, A. D., 2008. Rural Windfall or a New Resource Curse? Coca, Income, and Civil Conflict in Colombia. Review of Economics and Statistics 90(2), 191-215.

Apps, L., Gow, A. 2003. Male Witches in Early Modern Europe. Manchester University Press.

Bazzi, S., Blattman, C., 2014. Economic Shocks and Conflict: Evidence from Commodity Prices. American Economic Journal: Macroeconomics 6 (4), $1-38$.

Besley, T., Persson, T., 2010. State Capacity, Conflict, and Development. Econometrica 78 (1), 1-34.

Besley, T., Persson, T., 2011. The Logic of Political Violence. Quarterly Journal of Economics 126 (3), 1411-1445.

Blattman, C., Miguel, E., 2010. Civil War. Journal of Economic Literature 48 (1), 3-57.

Bloch, F., Rao, V., 2002. Terror as a Bargaining Instrument: A Case Study of Dowry Violence In Rural India. American Economic Review 92(4), 10291043.

Bloxham, D., 2008. Organized Mass Murder: Structure, Participation, and Motivation in Comparative Perspective. Holocaust and Genocide Studies 22 (2), 203-245.

Briggs, R., 1992. Witches and Neighbours. Penguin Books Ltd., New York.

Brown, K. M., 1992. Kingdom or Province? Scotland and the Regal Union, 1603-1715. MacMillan Press, London. 
Card, D., Gordon B. D., 2011. Family Violence and Football: The Effect of Unexpected Emotional Cues on Violent Behavior. Quarterly Journal of Economics 126 (1), 103-143.

Christia, F., 2008. Following the Money: Muslim versus Muslim in Bosnia's Civil War. Comparative Politics 40 (4), 461-480.

Collier, P. Hoeffler, A., 2004. Greed and Grievance in Civil War. Oxford Economic Papers 54 (4), 563-595.

Conley, T. G., 1999. GMM Estimation with Cross Sectional Dependence. Journal of Econometrics 92 (1), 1-45.

Cowan, E.J., 2008. Witch Persecution and Folk Belief in Lowland Scotland: The Devil's Decade. In: Goodare, J. (ed.), Witchcraft and Belief in Early Modern Scotland, Palgrave Macmillan, London.

Dal Bo, E., Dal Bo, P., 2011. Workers, Warriors, and Criminals: Social Conflict in General Equilibrium. Journal of the European Economic Association 9(4), 646-677.

Dell, M., 2015. Trafficking Networks and the Mexican Drug War. American Economic Review 105 (6), 1738-1779

Dell, M., 2017. The Historical State, Local Collective Action, and Economic Development in Vietnam. NBER Working Paper No. 23208.

DesBrisnay, G., 1986. Menacing Their Persons and Exacting Their Purses: The Aberdeen Justice Court, 1600-1800. In: Stevenson D. (Ed.), From Lairds to Louns: County and Burgh Life in Aberdeen, 1600-1800. Aberdeen University Press, Aberdeen.

Dillinger, J., 2013. Politics, State-Building, and Witch-Hunting. In: Levack, B. (Ed.), The Oxford Handbook of Witchcraft in Early Modern Europe and Colonial America. Oxford University Press, 528-547.

Dincecco, M., Katz, G., 2016. State Capacity and Long-run Economic Performance. Economic Journal 126 (590), 189-218.

Doss, C., 2013. Intrahousehold Bargaining and Resource Allocation in Developing Countries. World Bank Research Observer 28 (1), 52-78.

Dube, O., Vargas, J. F., 2013. Commodity Price Shocks and Civil Conflict: Evidence from Colombia. Review of Economic Studies 80 (4), 1384-1421.

Dudley, M., Goodare, J., 2013. Outside In or Inside Out: Sleep Paralysis and Scottish Witchcraft. In: Goodare, J. (Ed.). Scottish Witches and WitchHunters. Palgrave Macmillan, London. 
Elliot, K. A., 1998. The Sanctions Glass: Half Full or Completely Empty? International Security 23 (1), 50-65.

Fearon, J., Hoeffler, A., 2014. Benefits and Costs of the Conflict and Violence Targets for the Post-2015 Development Agenda. Copenhagen Consensus Assessment Paper.

Fetzer, T., 2014. Social Insurance and Conflict: Evidence from India. Mimeo.

Garfias, F., 2018. Elite Competition and State Capacity Development: Theory and Evidence from Post-Revolution Mexico. American Political Science Review 112 (2), 339-357.

Glaeser, E. L., 2005. The Political Economy of Hatred. Quarterly Journal of Economics 120 (1), 45-86.

Goodare, J., 2013. Witchcraft in Scotland. In: Levack, B. (Ed.), The Oxford Handbook of Witchcraft in Early Modern Europe and Colonial America. Oxford University Press, 300-317.

Goodare, J., 2010. The truth about witches and witch-hunters. The Guardian, http://www.theguardian.com/commentisfree/belief/2010/oct/30/halloweenwitches-history.

Goodare, J., 2002. Witch-hunting and the Scottish State. In: Goodare, J. (Ed.), The Scottish witch-hunt in context. Manchester University Press, 122-145.

Green, M.H., Jacob, R.H., 1991. Losses of sheep following adverse weather after shearing. Australian Veterinary Journal 69 (6), 142-143.

Grossman, H., 1999. Kleptocracy and Revolutions. Oxford Economic Papers $51(2), 267-283$.

Guiot, J., Corona, C., 2010. Growing Season Temperatures in Europe and Climate Forcings Over the Past 1400 Years. PLoS One 5 (4), 1-15.

Heldring, L., 2017. Violence and the State: Evidence from Rwanda's 'Decade of Atrocities'. Harvard University, mimeo.

Hillberg, R., 1961. The Destruction of the European Jews. Yale University Press.

Hirshleifer, J., 1991. The Technology of Conflict as an Economic Activity. American Economic Review Papers and Proceedings 81 (2), 130-134.

Holopainen, J., Helama, S., 2009. Little Ice Age Farming in Finland: Preindustrial Agriculture on the Edge of the Grim Reaper's Scythe. Human Ecology 37 (2), 213-225. 
Hsiang, S. M., Burke, M., Miguel, E., 2013. Quantifying the Influence of Climate on Human Conflict. Science 312 (6151).

Johnson, N.D., Koyoma, M., 2017. States and Economic Growth: Capacity and Constraints. Explorations in Economic History 64 (2), 1-20.

Jha, S., 2013. Trade, Institutions, and Ethnic Tolerance: Evidence from South Asia. American Political Science Review 107 (4), 806-832.

Larner, C., 1981. Enemies of God: The Witch-hunt in Scotland. Chatto \& Windus Ltd., London.

Leeson, P. T., Russ, J. W., 2018. Witch Trials. Economic Journal 129 (613), 2066-2105.

Levack, B., 2006. The Witch-Hunt in Early Modern Europe (3rd Edition). Pearson Education, United Kingdom.

Levack, B., 2008. Witchcraft in Scotland: Law, Politics, and Religion. Routledge, New York.

Lowes, S., Nunn, N., Robinson, J.A., Weigel, J., 2017. The Evolution of Culture and Institutions: Evidence from the Kuba Kingdom. Econometrica 85 (4), 1065-1091.

Marinov, N., 2005. Do Economic Sanctions Destabilize Country Leaders? American Journal of Political Science 49 (3), 564-576.

Michalopoulos, S., Papaioannou, E., 2013. Pre-colonial Ethnic Institutions and Contemporary African development. Econometrica 81 (1), 113-152.

Miguel, E.. 2005. Poverty and Witch Killing. Review of Economic Studies 72 (4), 1153-1172.

Miguel, E., Satyanath, S., Sergenti, E., 2004. Economic Shocks and Civil Conflict: An Instrumental Variables Approach. Journal of Political Economy 112 (4), 725-753.

Olesen, J. E., Bindi, M., 2002. Consequences of climate change for European agricultural productivity, land use and policy. European Journal of Agronomy 16 (2), 239-262.

Oster, E., 2004. Witchcraft, Weather and Economic Growth in Renaissance Europe. Journal of Economic Perspectives 18 (1), 215-228.

Parry, M. L., 1975. Secular Climatic Change and Marginal Agriculture. Transactions of the Institute of British Geographers 4, 1-13.

Paterson, L., 2013. Executing Scottish Witches. In: Goodare, J. (ed.). Scottish Witches and Witch-Hunters, Palgrave Macmillan, London. 
Rae, H., 2002. State Identities and the Homogenisation of Peoples. Cambridge University Press, Cambridge.

Ramankutty, N., Foley, J. A., 1999. Estimating Historical changes in Global Land Cover: Croplands from 1700 to 1992. Global Biogeochemical Cycles 13 (4), 997-1027.

Rogall, T., 2014. Mobilizing the Masses for Genocide. Stockholm School of Economics, mimeo.

Roper, L., 1994. Oedipus and the Devil: Witchcraft, Religion and Sexuality in Early Modern Europe. Routledge, London.

Rorke, M., 2005. The Scottish Herring Trade, 1470-1600. Scottish Historical Review 84 (2), 149-165.

Rowlands, A., 2013. Witchcraft and Gender in Early Modern Europe. In: Levack, B., (Ed.) The Oxford Handbook of Witchcraft in Early Modern Europe and Colonial America. Oxford University Press, 449-467.

Smout, T.C., 1973. A History of the Scottish People, 1560-1830. The Chaucer Press Ltd., UK.

Tilly, C., 1990. Coercion, Capital, and European States. Basil Blackwell, UK.

Torell, D.T., Weir, W.C., Bradford, G.E., Spurlock, G.M., 1969. Effects of Time of Shearing on Wool and Lamb Production. California Agriculture 23 (11), 16-18.

Voigtlander, N., Voth, H.-J., 2012. Persecution Perpetuated: The Medieval Origins of Anti-Semitic Violence in Nazi Germany. Quarterly Journal of Economics 128 (2), 469-530.

Waldinger, F., 2010. Quality Matters: The Expulsion of Professors and the Consequences for PhD Student Outcomes in Nazi Germany. Journal of Political Economy 188 (4), 787-831.

Waldinger, M. 2014. The Economic Effects of Long-Term Climate Change: Evidence from the Little Ice Age, 1500-1750. GRI Working Papers 214, Grantham Research Institute on Climate Change and the Environment.

Wasser, M., 2008. The Mechanical World-View and the Decline of Witch Beliefs in Scotland. In: Goodare, J. (Ed.), Witchcraft and Belief in Early Modern Scotland, Palgrave Macmillan, London.

Whyte, I., 1986. Agriculture in Aberdeenshire in the Seventeenth and Early Eighteenth Centuries: Continuity and Change. In: Stevenson, D. (Ed.), From Lairds to Louns: Country and Burgh Life in Aberdeen, 1600-1800. Aberdeen University Press. 
Yanagizawa-Drott, D., 2014 Propaganda and Conflict: Evidence from the Rwandan Genocide. Quarterly Journal of Economics 129 (4), 1947-1994.

Yeoman, L., 2002. Hunting the Rich Witch in Scotland: High-status Witchcraft Suspects and their Persecutors, 1590-1650. In: Goodare, J. (Ed.), The Scottish Witch-hunt in Context. Manchester University Press, 106-121.

Young, M., 2007. Scottish Crop Yields in the Second Half of the Seventeenth Century: Evidence from the Mains of Castle Lyon in the Carse of Gowrie. Agricultural History Review 55 (1), 51-74. 